\title{
Transformational Leadership and Work Engagement in the Automotive Retail Industry: A Study of South Africa
}

\author{
Abhinanda Gautam ${ }^{1}$, \& Eben Enslin ${ }^{2}$ \\ ${ }^{1}$ Dr., Academic Head, Regenesys Business School, South Africa \\ ${ }^{2}$ Alumnus, Regenesys Business School, South Africa \\ Correspondence: Abhinanda Gautam, Dr., Academic Head, Regenesys Business School, South Africa.
}

Received: December 10, 2018

Accepted: April 10, 2019

Online Published: April 26, 2019

doi:10.5539/ibr.v12n5p133

URL: https://doi.org/10.5539/ibr.v12n5p133

\begin{abstract}
Real leadership is needed in the automotive industry's competitive environment to guide subordinates so that they share goals, attitudes, values, and work towards the achievement of organisational strategies. Macroenvironmental changes such as the slowdown in the South African economy, labour unrest, high unemployment levels, a weakening currency, and new vehicle price increases have had a detrimental effect on automotive retailers and can be blamed partially for dealers struggling to reach targets in recent years. This perpetually fluctuating external environment promotes corresponding internal automotive dealership changes and strategies. This might mean changes to intangible resources like dealership processes, policies, procedures, or physical resources like people, demographics, materials and products. In both cases, strong leadership is required.

The primary aim of this exploratory study was to determine whether sales managers exhibited a predominately transactional or transformational leadership style, and to understand current levels of work engagement of sales executives in motor dealerships' new and used vehicle sales departments. A secondary aim was to examine the correlation between the prevailing leadership style (either transactional or transformational) of sales managers and the level of work engagement of sales executives.

The research method included a formal quantitative, cross-sectional survey. Data was collected using questionnaires developed by international researchers in the field of transformational and transactional leadership and work engagement. The main findings of this research will contribute to current literature and knowledge relating to work engagement and its interdependence with transformational and transactional leadership.
\end{abstract}

Keywords: leadership, work engagement, automobile industry

\section{Introduction}

The perpetually fluctuating external environment promotes corresponding internal automotive dealership changes and strategies in intangible resources like processes, policies, and procedures, or in tangible resources like people, materials and products. These external changes push leaders to deliver concrete results with the assistance of subordinates in such a way that subordinates live the vision, achieve departmental goals, align to work values and work towards the achievement of organisational strategies (Bartram \& Casimir, 2007, p. 12). Effective leadership is required for the successful implementation of organisational change in the modern workplace (Groenewald \& Ashfield, 2008, p. 56). Kotter (1996, p.67) suggests that the effectiveness of leadership can be measured by how well leaders align subordinates to the vision of the business and by producing the required results.

Over time a well-defined people strategy cultivates better organisational awareness, improves employees' abilities, creates higher levels of efficiency, improves internal and external relationships and delivers greater profit (Bezuidenhout \& Schultz, 2013, p. 2). The leadership style that managers use is, therefore, critical in determining the level of work engagement displayed by their employees.

\subsection{Background to the Study}

South Africa is regarded as an important emerging market, and its automotive industry is a key segment of the 
economy (Automotive Industry Export Council, 2011, p. 7; South Africa Info, 2012), regarded as a key indicator. The automotive segment contributes on average a minimum of $6 \%$ to the country's gross domestic product (GDP) and accounts for $12 \%$ of South Africa's manufacturing exports. Despite the volatile environment domestic automotive sales and exports have grown since 2009 (Automotive Industry Export Council, 2014, p. 4). Based on data collated in 2014, industry capital expenditure was projected at a (then) record high of R7.9-billion (National Association of Automobile Manufacturers of South Africa, 2015).

The industry is an important employer in South Africa. In 2014 it employed an estimated 28000 people in automotive manufacturing, 65000 people in component manufacturing an estimated 200000 people in automotive retail outlets, and approximately 6600 in the tyre manufacturing industry.

South Africa's automotive segment consists of:

- Original equipment manufacturers (OEM) and passenger and commercial automotive assemblers.

- Vehicle component manufacturers, who constitute the first tier in the supply chain.

- Suppliers of original automotive parts and accessories.

- Automotive retail and aftermarket sales. These markets include new vehicle and used vehicle sales departments, parts sales, and servicing of vehicles through listed groups, independent retailers and repair shops (Naude, 2013, p. 408). At the end of September 2014, 28988 people were employed in retail dealerships (National Association of Automobile Manufacturers of South Africa, 2015).

Following years of consecutive growth, year-on-year declines in new vehicle sales were recorded in 2014 and 2015 as the economy slowed, and interest rates and new vehicle prices rose (National Association of Automobile Manufacturers of South Africa, 2015).

\section{Literature Review}

Leadership has remained an important social sciences subject and a fascinating phenomenon that occurs in all groups of people regardless of organisation, location, nationality and culture. According to (Alvesson \& Sveningsson, 2003, p. 1436), leadership creates results and encourages managers to become active, influential and powerful. The leader acts, and the subordinate responds (. Howell \& Costley (2006, p. 4) define leadership as a method of influencing subordinates to achieve goals, while Barker (1997, p. 349) suggests that a leader is someone who can create change and new patterns of thinking, beliefs and actions in their subordinates.

James MacGregor Burns, in 1978, was first to separate leadership into two distinct types: transactional leadership and transformational leadership. Transformational leadership has since become a popular and accepted approach to leadership and has been the focus of much recent research (Northouse, 2016, p. 161). Transformational leaders recognise their subordinates' needs and are able to help them develop their potential (Avolio \& Bass, 2004, p. 18) in a life-long process. Transactional leadership, in contrast, clearly defines such leaders' expectations and promotes performance so that results can be achieved. Key behaviours of transactional leadership include providing rewards for achievement and monitoring mistakes.

More than 30\% of articles listed in Leadership Quarterly related to transformational leadership (Northouse, 2016, p. 161), making clear researchers' interest in this progressive approach to changing people. Research suggests that using a transformational leadership style creates a work climate where subordinates feel enthusiastic about their work and where they improve results, not only for the organisation, but also for themselves (Baumruk, Gorman, \& Gorman, 2006, p. 25).

During a study of 130 MBA students at Regenesys Business School, 2017, each student's subordinates were asked to complete the Raters Multifactor Leadership Questionnaire (MLQ). The results from this study confirmed the point that Bass (1985) emphasised: that subordinates put in more effort and can achieve more effectiveness and greater levels of satisfaction when they work with a transformational leader.

Transformational leaders attract strong feelings of identity and intense emotions in subordinates as measured by idealised influence (both attributes and behaviours). They also create excitement at work and heightened expectations as measured by inspirational motivation. They nurture one-on-one relationships and show high levels of empathy as measured by individualised consideration. They also create interest and curiosity in ideas and new methods as measured by intellectual stimulation.

Nemanich and Keller (2007) investigated the influence of transformational leadership on 447 employees at a multinational organisation that merged with another organisation. Their research revealed that transformational leadership behaviours such as promoting an idealised future, inspirational motivation, individualised consideration and intellectual stimulation were positively related to job performance and organisational 
performance (Northouse, 2016, p. 170). A study of 220 employees by (Rowold and Heinitz 2007, p. 181) in Germany revealed that transformational leadership increased the impact of employee performance on company profit (Northouse, 2016, p. 170).

Transactional leaders focus on task-orientated behaviour such as goal setting, monitoring performance and providing consequences for both success and failure (Gibson, Ivancevich, Donnely, \& Konopaske, 2012, p. 356). Transactional leadership is seen as a contractual relationship that may either be spoken or unspoken as the leader trades promises of remuneration or punitive consequences for expected work (Avolio \& Bass, 2004, p. 22).

Historically, the business was based on transactional leadership, with leaders giving subordinates something they want in exchange for something that the leaders want. These leaders motivate their subordinates by fulfilling their physiological and basic human needs, exchanging tangible rewards for desired outcomes. For example, giving employees financial bonuses for going the extra mile or for reaching certain targets. The leader rewards subordinates when they achieve agreed objectives and helps them to accomplish these goals (Gibson, Ivancevich, Donnely, \& Konopaske, 2012, p. 314). Bass (1985) described active transactional leadership as positive contingent reward or management by exception - or, in passive form - laissez-faire management (Felfe, Tartler, \& Liepmann, 2004).

Transactional leadership is about a "fair negotiation" concerning the demands and rewards of both parties. The leader and subordinate discuss what goals need to be achieved as well as the resources required and conditions that need to be met to reach their aims. The transactional leader clarifies the tasks, responsibilities, structures, terms and expectations to arrive at the outcomes (Felfe, Tartler, \& Liepmann, 2004).

Professor Peter Drucker said: "People are like electricity, of no use unless switched on." Work engagement is a relatively new research field. Khan (1990, p. 694) first theorised engagement as the harnessing of organisational employees' selves to their work roles. In engagement, people commit and express themselves physically, cognitively, emotionally and mentally in their job performances. A more modern definition of work engagement is the extent to which employees commit to something or someone in their organisation, how hard they work, and the duration of their stay because of that commitment (Corporate Leadership Council, 2004). (Pech and Slade, 2006) state that employee engagement is an important factor in organisational success (Perch \& Slade, 2006, p. 24). Levels of work engagement have a considerable impact on the productivity and output of organisations (Havenga, Stanz, \& Visagie, 2011). The Corporate Leadership Council's (2004) findings indicate that employees who are engaged perform $20 \%$ better and are $87 \%$ less likely to resign from their jobs.

Engagement is defined as the "combination of a positive psychological contract and the willingness or eagerness to offer discretionary behaviour" (Chartered Institute of Personnel and Development, 2009). It is proposed, based on their empirical findings, that work engagement predicts performance, organisational success and shareholder return. However, empirical findings suggest that the majority of employees are disengaged in the workplace and that this engagement gap that is costing organisations in lost productivity (Havenga, Stanz, \& Visagie, 2011).

\section{Research Methodology}

The blueprint for fulfilling the research objectives is the research design (Cooper \& Schindler, 2014, p. 665). An electronic survey was used to collect quantitative data for this study. The data were analysed by means of descriptive and inferential statistics. The results obtained were used to propose possible reasons for specific associations between the variables.

Sampling can be defined as the process of choosing elements from a population to represent the population (Cooper \& Schindler, 2014, p. 665). Nonprobability (or judgmental) sampling was used in this study. Judgmental sampling enables the researcher to use his or her own judgment to select cases that will best enable the researcher to answer the research questions and to meet the objectives (Saunders, Lewis, \& Thornhill, 2009, p. 268).

\subsection{Instrument Used to Collect the Primary Data}

For the purpose of this research, a questionnaire was formulated using the existing and published instruments of Bass \& Avolio (1995), the MLQ Multifactor Leadership Questionnaire, and Schaufeli \& Bakker's (2003) Utrecht Work Engagement Questionnaire. The reliability and validity of these two instruments (MLQ X5 and UWES-9) justified the choice for conducting quantitative research on the attributes of leadership and work engagement.

Section A of the questionnaire incorporated nine biographical elements in the form of five questions that offered the respondent a list of responses regarding age, gender, ethnic group, home language and qualification. It also included four questions relating to the position of the respondent (new or used vehicles), the name of the dealership, name of the automotive brand and the number of months of service at the dealership. 
Section $\mathbf{B}$ of the questionnaire consisted of 36 items in the form of rating questions. Rating questions are regularly used to collect opinion data (Saunders, Lewis, \& Thornhill, 2009, p. 378).

The questions were presented in a five-point Likert-style rating scale in which respondents were asked how strongly they agreed or disagreed with a statement. A range of possible responses related to each of the questions was provided. For the purpose of this research, nine scales based on the MLQ 5X, directly related to transactional and transformational leadership were measured in part B of the questionnaire. The nine scales measured were:

1. Idealised attributes or idealised influence (attributes)

2. Idealised behaviours or idealised influence (behaviours)

3. Inspirational motivation

4. Intellectual stimulation

5. Individual consideration

6. Contingent reward

7. Management by exception (active)

8. Management by exception (passive)

9. Laissez-faire or passive avoidance

For the purpose of this research, three scales based on the UWES - 9 Work Engagement questionnaire directly related to engagement were measured in part $\mathrm{C}$ of the questionnaire. The three scales measured were vigour, dedication and absorption.

Table 3.1 shows the scales that were measured, the abbreviations used and which questions tested which specific scale.

Table 3.1. Work Engagement Scales

\begin{tabular}{ccccc}
\hline Characteristic & Scale Name & Scale Abbreviation & Questions & No of Questions testing the scale \\
\hline \multirow{2}{*}{ Engagement } & Vigour & VI & $1,4,8,12,15,17$ & 6 \\
& Dedication & DE & $2,5,7,10,13$ & 5 \\
& Absorption & AB & $3,6,9,11,14,16$ & 6 \\
\hline
\end{tabular}

Table 3.2 highlights the scales that were measured, the abbreviations used and which questions tested which specific scale.

Table 3.2. Transformational Leadership Scales

\begin{tabular}{|c|c|c|c|c|}
\hline Characteristic & Scale Name & $\begin{array}{c}\text { Scale } \\
\text { Abbreviation } \\
\end{array}$ & Questions & $\begin{array}{l}\text { No of questions } \\
\text { testing the scale }\end{array}$ \\
\hline Transformational & $\begin{array}{l}\text { Idealised Attributes or } \\
\text { Idealised Influence } \\
\text { (Attributes) }\end{array}$ & IA or II (A) & $10,18,21,25$ & 80 \\
\hline Transformational & $\begin{array}{c}\text { Idealised Behaviours } \\
\text { or Idealised Influence } \\
\text { (Behaviours) }\end{array}$ & IB or II (B) & $6,14,23,34$ & 4 \\
\hline Transformational & Inspirational Motivation & IM & $9,13,26,36$ & 4 \\
\hline Transformational & Intellectual Stimulation & IS & $2,8,30,32$ & 4 \\
\hline Transformational & Individual Consideration & IC & $15,19,29,31$ & 4 \\
\hline Transactional & Contingent Reward & CR & $1,11,16,35$ & 4 \\
\hline Transactional & $\begin{array}{c}\text { Management by Exception } \\
\text { (Active) }\end{array}$ & MBEA & $4,22,24,27$ & 4 \\
\hline Transactional & $\begin{array}{l}\text { Management by Exception } \\
\text { (Passive) }\end{array}$ & MBEP & $3,12,17,20$ & 4 \\
\hline Passive Avoidant & Laissez-faire & LF & $5,7,28,33$ & 4 \\
\hline
\end{tabular}

The target population for this research study was vehicle sales executives within the dealerships division of a leading automotive retailer with a national footprint of retail outlets situated throughout Southern Africa. The employees considered for this study were those who were in a vehicle sales role and who had a direct influence on the retail success of each of the business units of the division. These employees, totaling 456, were either in a new vehicle or used vehicle sales positions.

The data required for this research was gathered using a self-administered questionnaire, which was distributed to and collected from the respondents via e-mail. All responses were treated as anonymous. 
Empirical research indicates that discretionary effort (going above and beyond the job description) in the workplace is a direct result of high levels of work engagement (Bezuidenhout \& Schultz, 2013, p. 2). The academic literature suggests there are various drivers that can improve levels of engagement, including the chosen leadership style of managers. This research tested the validity of these studies in the automotive retail industry of South Africa.

\subsection{Research Objectives}

1. To ascertain whether the dominant leadership style in a specific automotive dealer group was transactional or transformational; and

2. To ascertain whether the levels of engagement exhibited by respondents were greater under either dominant transactional or transformational leadership styles.

\subsection{Hypotheses and Research Design}

Testing the probability of a pattern-like relationship between variables occurring by chance alone is known as hypothesis testing (Saunders, Lewis, \& Thornhill, 2009, p. 450). The statistical analysis consists of a test statistic, the degrees of freedom (df) and the probability (p-value) of the test result being statistically significant. If the probability of the statistic is a result of chance and is very low (usually $\mathrm{p}<0.05$ or less than 1 ), then there is a statistically significant relationship. Various statistical tests were applied during this study to test the alternative hypotheses. These included descriptive statistics, correlation tests, Anova tests and T tests. Statistical software packages were used for the statistical analysis (SPSS23).

The following hypotheses were formulated in the research article:

Hypothesis 1: The dominant leadership style used by sales managers in the automotive motor industry is mainly transactional.

Hypothesis 2: There is a direct positive relationship between high levels of work engagement and transformational leadership.

\subsection{Construct Reliability and Convergent Validity Tests}

\subsubsection{Transactional Leadership}

Three items were retained for transactional leadership which are mainly the items of Management by Exception Passive (Items B3, B12 and B20). The remaining transactional items can be used to get the opinion of respondents on these questions, but they cannot be used as part of the transactional leadership construct because the scale would become unreliable and invalid. The Cronbach alpha of these 3 items is .695 which is close to .7 as seen in table 3.3. This result is acceptable; meaning the items used to measure transactional leadership measure up $69 \%$ of the construct; so the scale transactional leadership has an acceptable level of reliability.

Table 3.3. Reliability Transactional Leadership

\begin{tabular}{cc}
\hline Cronbach's Alpha & N of Items \\
\hline .695 & 3 \\
\hline
\end{tabular}

Concerning convergent validity, the item-total statistic table in table 3.4 below indicates an acceptable degree of convergent validity given that all three items correlate almost (.480) or above .5 with the rest of the construct.

Table 3.4. Transactional item-total statistics

\begin{tabular}{ccc}
\hline & Corrected Item-Total Correlation & Cronbach's Alpha if Item Deleted \\
\hline B3_1 & .524 & .585 \\
B20_1 & .527 & .581 \\
B12_1 & .480 & .640 \\
\hline
\end{tabular}

3.4.2 Transformational Leadership

20 items proposed by the researcher were retained for transformational leadership (B2, B6, B8, B9, B10, B13, B14, B15, B18, B19, B21, B23, B25, B26, B29, B30, B31, B32, B34 and B36). The Cronbach alpha of these 20 items is .972, which is above .7; therefore, the transformational leadership scale used in this study has good reliability. Table 3.5 below indicates the reliability test.

Table 3.5. Reliability Transformational Leadership

\begin{tabular}{cc}
\hline Cronbach's Alpha & N of Items \\
\hline .972 & 20 \\
\hline
\end{tabular}

Concerning convergent validity, the item- total statistic in table 3.6 below indicates a good convergent validity in that all items correlate above .5 with the rest of the construct. 
Table 3.6. Transformational item-total statistics

\begin{tabular}{lcc}
\hline & Corrected Item-Total Correlation & Cronbach's Alpha if Item Deleted \\
\hline B2_1 & .685 & .971 \\
B6_1 & .611 & .972 \\
B8_1 & .540 & .973 \\
B9_1 & .760 & .971 \\
B10_1 & .875 & .969 \\
B13_1 & .808 & .970 \\
B14_1 & .830 & .970 \\
B15_1 & .816 & .970 \\
B18_1 & .873 & .969 \\
B19_1 & .754 & .971 \\
B21_1 & .889 & .969 \\
B23_1 & .831 & .970 \\
B25_1 & .617 & .972 \\
B26_1 & .859 & .970 \\
B29_1 & .644 & .972 \\
B30_1 & .830 & .970 \\
B31_1 & .889 & .969 \\
B32_1 & .869 & .969 \\
B34_1 & .819 & .970 \\
B36_1 & .860 & .969 \\
\hline
\end{tabular}

3.4.3 Laissez-Faire Leadership

Four items proposed by the researcher were retained for laissez-faire leadership (B5, B7, B28 and B33). The Cronbach alpha of these four items is .804 which is above .7; therefore, the scale Laissez-Faire leadership is reliable. Table 3.7 below indicates the Cronbach alpha test.

Table 3.7. Reliability Laisses-Faire Leadership

\subsubsection{Work Engagement}

\begin{tabular}{cc}
\hline Cronbach's Alpha & N of Items \\
\hline .804 & 4 \\
\hline
\end{tabular}

Fourteen items were retained for Work Engagement (C1, C2, C3, C4, C5, C6, C7, C8, C9, C10, C11, C12, C14, $\mathrm{C} 15, \mathrm{C} 16$ and C17). Item 13 was excluded to improve the reliability of the scale. The Cronbach alpha of these 14 items is .916 which is above .7; therefore, the scale Work Engagement is reliable. Table 3.8 below highlights the results of the Cronbach alpha test.

Table 3.8. Reliability work engagement

\begin{tabular}{cc}
\hline Cronbach's Alpha & N of Items \\
\hline .916 & 14 \\
\hline
\end{tabular}

The item-total statistic in table 3.9 below indicates a good convergent validity for that all items that have a correlation value above .5 with the rest of the construct.

Table 3.9. Work engagement item-total statistics

\begin{tabular}{lcc}
\hline & Corrected Item-Total Correlation & Cronbach's Alpha if Item Deleted \\
\hline C3_1 & .581 & .912 \\
C4_1 & .787 & .905 \\
C5_1 & .781 & .906 \\
C6_1 & .605 & .912 \\
C7_1 & .709 & .908 \\
C8_1 & .771 & .905 \\
C9_1 & .674 & .910 \\
C10_1 & .755 & .908 \\
C11_1 & .694 & .909 \\
C12_1 & .585 & .912 \\
C14_1 & .457 & .918 \\
C15_1 & .524 & .915 \\
C16_1 & .546 & .915 \\
C17_1 & .573 & .913 \\
\hline
\end{tabular}

\subsubsection{Construct Discriminant Validity}

Discriminant validity ensures that the items used to measure one construct, only measure that specific construct. These items cannot be used to measure another construct. This statistically translates into the low correlation between constructs. In this case, we note in table 3.10 that the constructs are not strongly correlated given that all 
correlation coefficients are below 0.8 ; these results indicate an acceptable level of discriminant validity among the constructs.

Table 3.10. Construct Discriminant Validity

\begin{tabular}{llcc}
\hline & & Transformational leadership & Transactional leadership \\
\hline Transformational leadership & Pearson Correlation & 1 & $-.602^{* *}$ \\
& Sig. (2-tailed) & & .000 \\
Transactional leadership & $\mathrm{N}$ & 191 & 191 \\
& Pearson Correlation & $-.602^{* *}$ & 1 \\
& Sig. (2-tailed) & .000 & 191 \\
\hline
\end{tabular}

\section{Hypotheses Testing}

\subsection{Hypothesis 1}

The dominant leadership style used by sales managers in the automotive motor industry is mainly transactional. To test the hypothesis 1, descriptive statistics were performed and results are indicated in Table 4.1.

Table 4.1. Descriptive statistics for hypothesis 1

\begin{tabular}{lccc}
\hline & Mean & Std. Deviation & $\mathrm{N}$ \\
\hline Transformational leadership & 2.527 & 1.002 & 191 \\
Transactional leadership & 1.279 & .989 & 191 \\
\hline
\end{tabular}

According to Table 4.1, transformational leadership is the dominant style because it has a greater mean (2.527). Transactional leadership is calculated with a mean of 1.279 .

\subsection{Hypothesis 2}

There is a direct positive relationship between work engagement and transformational leadership. To test the hypothesis 2, a Pearson correlation test was performed and results are indicated in Table 4.2.

Table 4.2. Correlation test between engagement and transformational leadership

\begin{tabular}{cccc}
\hline & & Work Engagement & Transformational Leadership \\
\hline Work Engagement & Pearson Correlation & 1 & $.482^{* *}$ \\
& Sig. (2-tailed) & & .000 \\
& $\mathrm{~N}$ & 191 & 191 \\
\hline Transformational leadership & Pearson Correlation & $.482^{* *}$ & 1 \\
& Sig. (2-tailed) & .000 & 191 \\
\hline & $\mathrm{N}$ & 191 & $* *$ Correlation is significant at the 0.01 level (2-tailed) \\
\hline
\end{tabular}

Table 4.2 indicates a significant associative relationship between work engagement and transformational leadership in the South African automotive industry because the correlation coefficient (.482) has a significant p-value (.000 that is smaller than.05). According to Evans the correlation in this research appears to be a moderate positive correlation, which suggests that improvement in transformational leadership can lead to improved work engagement. Conclusion: Hypothesis 2 was accepted as it indicates a moderate positive correlation between work engagement and transformational leadership.

\section{Limitations of the Study}

This study was limited to the automotive retail sector, focusing on one listed retailer. The response rate for this study was 191 from a population of 456 new and used sales executives from different OEM groups. The sampling method used in this study was judgemental and therefore the results cannot be projected to the whole automotive retail sector in South Africa.

\section{Conclusion}

This research dissertation attempted to establish the current level of work engagement expressed by employees exposed to two predominant leadership styles in the sales departments of a retail automotive dealership group. The findings indicated that transformational leadership moderately influences work engagement more than transactional leadership. This research also established the current dominant leadership style practised by sales managers in the automotive retail environment is transformational. Organisational executives should focus simultaneously on understanding the broader aspects of work engagement within an organisation as well as providing constant support to develop the leadership skills of managers, particularly transformational leadership skills.

Organisations should focus on developing the following leadership skills in their managers: 
1. The idealised influence of leaders, so that leaders know how to act as role models for subordinates, and consequently subordinates want to emulate them.

2. The inspirational motivation of leaders and their effectiveness in communicating their expectations to subordinates. Leaders promote team spirit, which influences the subordinates' to put concentrated efforts towards productivity.

3. Leaders must intellectually stimulate their subordinates and allow their subordinates to be creative. Leaders should foster participation and creativity, which challenge the subordinates' to find improved practices and modern approaches whilst solving organizational issues.

4. The individualised consideration of how leaders are able to create a supportive environment where they listen to the specific needs of subordinates. The focus should be on coaching and use delegation to help subordinates to grow through their work challenges.

Finally, statistical analysis of the data infers that managers' chosen leadership style, whether transactional or transformational, moderately influences employees' level of work engagement. However, transformational leadership creates higher levels of work engagement.

\section{References}

Automotive Industry Export Council. (2011). Automotive Export Manual. AIEC. Pretoria: AIED.

Automotive Industry Export Council. (2014). South African Automotive Export Manual 2014. Pretoria: AIDC.

Avolio, B. J., \& Bass, B. M. (2004). Multifactor Leadership Questionnaire. 2004, Third. Mind Garden

Bakker, A. B., \& Demerouti, E. (2008). Towards a model of work engagement. Career Development International. https://doi.org/10.1108/13620430810870476

Bakker, A. B., Schaufeli, W. B., Leiter, M. P., \& Taris, T. W. (2008, uly-September 2008). Work engagement: An emerging concept in occupational health psychology. Work \& Stress, 22(3), 187-200. https://doi.org/10.1080/02678370802393649

Barker, R. A. (1997). How can we train leaders if we don't know what leadership is? Human Relations, 50. https://doi.org/10.1177/001872679705000402

Barker, R. A. (2001). The nature of leadership. Human Relations, 54(4), 469-494. https://doi.org/10.1177/0018726701544004

Bartram, T., \& Casimir, G. (2006). The relationship between leadership and follower in-role performance and satisfaction with the leader. Leadership \& Organization Development Journal, 28(1), 4-19. https://doi.org/10.1108/01437730710718218

Bass, B. M., \& Avolio, B. J. (1993). Transformational leadership: A response to critiques. In M. M. Chemers, \& R. Aynab, Leadership theory and research: Perspectives and directions (pp. 49-80). San Diego: Academic Press.

Bass, B. M., \& Avolio, B. J. (1994). Improving Organisational Operational Effectiveness Thousand Oaks, CA: Sage.

Bass, B. M., \& Avolio, B. J. (1995). MLQ Multifactor Questionnaire for research: Permission set. Redwood City: Mindgarden.

Bass, B. M., \& Riggio, R. E. (2006). Transformational Leadership (2nd ed.). London: Lawrence Erlbaum Associates.

Baumruk, R., Gorman, R. E., \& Gorman, B. J. (2006). Why managers are crucial to increasing engagement. Strategic HR Review , 5(2), 24-27. https://doi.org/10.1108/14754390680000863

Bezuidenhout, A., \& Schultz, C. (2013). Transformational Leadership and Employee Engagement In The Mining Industry. Journal of Contemporary Management, 10.

Charted Institute of Personnel and Development. (March 2011). Management competencies for enhancing employee engagement. London: CIPD.

Chartered Institute of Personnel and Development. (2009). Employee Engagement.Retrieved 2014 йил 15-09 from cipd.co.uk: http://cipd.co.uk/subjects/empreltns/general/empengmt

Chartered Institute of Personnel and Development. (2014, 12 29). Employee engagement. Retrieved 12 29, 2014, from CIPD: http://www.cipd.co.uk/hr-resources/factsheets/employee-engagement.aspx 
Cooper, D. R., \& Schindler, P. S. (2010). Business Research Methods (11th ed.). International Edition, USA: McGraw Hill .

Cooper, D. R., \& Schindler, P. S. (2014). Business Research Methods (12 ed.). New York: McGraw-Hill.

Corporate Leadership Council. (2004). Driving performance and retention through employee engagement. London: Corporate Executive Board.

Felfe, J., Tartler, K., \& Liepmann, D. (2004). Advanced Research in the Field of Transformational Leadership. https://doi.org/10.1177/239700220401800302

Gibson, J. L., Ivancevich, J. M., Donnely, J. H., \& Konopaske, R. (2012). Organizations. Behaviour, Structure, Process (Fourteenth ed.). Boston: McGraw-Hill.

Groenewald, A., \& Ashfield, G. (2008). When leaders are also explorers. The Star Workplace, 7 May, p. 56.

Havenga, W., Stanz, K., \& Visagie, J. (2011). Evaluating the difference in employee engagement before and after business and cultural transformation interventions. African Journal of Business Management, 5(22), 8804-8820. https://doi.org/10.5897/AJBM10.1436

Howell, J. P., \& Costley, D. L. (2006). Understanding Behaviours for Effective Leadership. Pearson.

Khan, W. A. (1990). Psychological conditions of personal engagement and disengagement at work. The Acadamy of Management Journal, 33(4), 692-724. https://doi.org/10.5465/256287

National Association of Automobile Manufacturers of South Africa. (2015, 01 07). Naamsa Media Release 2014. Retrieved 01 21, 2015, from NAAMSA: http://www.naamsa.co.za/flash/press.html

Nemanich, L. A., \& Keller, R. T. (2007). Transformational leadership in an acquisition: A field study of employees. The Leadership Quarterly, 18(1), 49-68. https://doi.org/10.1016/j.leaqua.2006.11.003

Northouse, P. G. (2016). Leadership: Theory and Practice (7th ed.). Thousand Oaks, CA: Sage.

Perch , R., \& Slade, B. (2006). Employee disengagement: is there evidence of a growing problem? Handbook of Business Strategy, 7(1), 21-25. https://doi.org/10.1108/10775730610618585

Powell, R. (2004). Basic Research for Librarians. Westport: Libraries Unlimited.

Rowold, J., \& Heinitz, K. (2007). Transformational and charismatic leadership: Assessing the convergent, divergent and criterion validity of the MLQ and the CKS. The Leadership Quarterly, 18(2), 121-133. https://doi.org/10.1016/j.leaqua.2007.01.003

Saunders, M., Lewis, P., \& Thornhil, A. (2007). Research methods for business students (Fourth ed.). Essex, England: Pearson Education Limited.

Saunders, M., Lewis, P., \& Thornhill, A. (2009). Research methods for business students (Fifth edition ed.). Essex: Pearson Education Limited.

Schaufeli, W., \& Bakker, A. (2003). Utrecht Work Engagement Scale. 1-58. Occupational Health Psychology Unit Utrecht University. https://doi.org/10.1037/t07164-000

Schaufeli, W., \& Bakker, A. B. (May 2004). Job demands, job resources, and their relationship with burnout and engagement: a multi-sample study. Journal of Organizational Behavior, 25(3), 293-315. https://doi.org/10.1002/job.248

\section{Copyrights}

Copyright for this article is retained by the author(s), with first publication rights granted to the journal.

This is an open-access article distributed under the terms and conditions of the Creative Commons Attribution license (http://creativecommons.org/licenses/by/4.0/). 